\title{
Açık ve Uzaktan Öğrenmede Sorularla Zenginleştirilmiş Etkileşimli Video Kullanımı*
}

\author{
Serpil KOÇDAR, Abdulkadir KARADENIZ, Aras BOZKURT, Köksal BÜYÜK**
}

Açık ve Uzaktan Öğrenmede Sorularla Zenginleştirilmiş Etkileşimli Video Kullanımı

Özet

Bu çalışmanın amacı, uzaktan öğrenenlere yönelik geliştirilen sorularla zenginleştirilmiş etkileşimli videoların kullanımına ilişkin öğrenenlerin görüşlerinin alınması ve bu görüşlere bağlı olarak kullanılabilirlik, öğrenen memnuniyeti ve gereklilik düzeylerinin araştııımasıdır. Araştırma kesitsel tarama çalışması olarak desenlenmiştir. Araştırmada 2393 öğrenenden anketle nicel veriler toplanmıştır. Bunun yanı sıra, öğrenme analitikleri, video altlarına eklenen puanlamalar ve hata bildirim verileri kullanılmıştır. Araştırmada elde edilen bulgulara göre öğrenenler sorularla zenginleştirilmiş etkileşimli videoları kolay kullanılabilir ve faydalı buldukların belirterek bu videoların etkili, verimli ve çekici öğrenme deneyimi yaşamalarına katkıda bulunduğunu söylemişlerdir. Ayrıca, araştırmada öğrenenlerin sorularla zenginleştirilmiş etkileşimli videoları kullanma konusunda memnuniyet düzeyleri yüksek bulunmuş olup, öğrenenler bu tür videoların yaygınlaştııımasını istemektedirler.

Anahtar Kelimeler: Açık ve Uzaktan Öğrenme, Uzaktan Eğitim, Sorularla Zenginleştirilmiş Etkileşimli Video, Öğrenen-içerik Etkileşimi

\section{Giriş}

Eğitsel videolar, açık ve uzaktan öğrenme ortamlarında yaygın olarak kullanılan ders malzemelerinden biridir. Kullanılmaya ilk başlandığında eğitsel videolar tek yönlü iletişim sağlaması nedeniy-

\footnotetext{
* Bu çalışma Anadolu Üniversitesi Bilimsel Araştırma Projeleri Komisyonu tarafından kabul edilen 1703 E061 no.lu proje kapsamında desteklenmiştir.

${ }^{* *}$ Serpil KOÇDAR, Yrd.Doç.Dr., Anadolu Üniversitesi, Uzaktan Öğretim Bölümü, skocdar@anadolu.edu.tr; Abdulkadir KARADENIZ, Yrd.Doç.Dr., Anadolu Üniversitesi, Uzaktan Öğretim Bölümü, abdulkadir.karadeniz@gmail.com; Aras BOZKURT, Uzm..Dr., Anadolu Üniversitesi, Uzaktan Öğretim Bölümü, arasbozkurt@gmail.com; Köksal BÜYÜK, Doç.Dr., Anadolu Üniversitesi, Uzaktan Öğretim Bölümü, koksalbuyuk@anadolu.edu.tr
} 
le öğrenenlerin pasif öğrenme deneyimleri yaşamalarına yol açarken, teknolojinin sunduğu avantajlar sayesinde artık eğitsel videolara farklı türde etkileşimler eklenebilmektedir (Wachtler, Hubmann, Zöhrer ve Ebner, 2016; Wilson, 2016). Bu etkileşimler oynatma, durdurma, ileriye ve geriye sarma, sununun hızını ve yönünü değiştirme, sorular, kısa sınavlar, geribildirimler, not alma, ek kaynaklar arama ve benzeri türden öğeleri içermektedir (Delen, Liew ve Willson, 2014; Dong ve Goh, 2015; Schwan ve Riempp, 2004). Yapılan araştırmalar videolara eklenen etkileşim öğelerinin öğrenenlerin dikkatlerini anlatılan konu üzerine çekme ve böylelikle daha iyi öğrenmeyi sağlama açısından önemli bir unsur olduğunu ortaya koymaktadır (Geri, Winer ve Zaks, 2017; Wilson, 2016; Vural, 2013; Zhang, Zhou, Briggs ve Nunamaker, 2006). Videolara etkileşim unsurlarının eklenmesi öğrenen-içerik etkileşiminin artııımasını; böylece öğrenenlerin pasif izleyici olmaktan çıkıp aktif katılımcı durumuna geçmesini sağlar (Uğur ve Okur, 2016; Wachtler vd., 2016; Zhang vd., 2006).

Öğrenenlerin öğreticilerden, diğer öğrenenlerden ve öğrenme kaynaklarından yer ve/veya zaman açısından ayrı olduğu ve aralarındaki iletişimin etkileşimli iletişim teknolojileriyle sağlandığı açık ve uzaktan öğrenme uygulamalarında öğrenen-içerik etkileşimi önemli bir unsurdur (Aydın, 2011; Moore ve Kearsley, 2012). Özellikle kendi kendine çalışma esasına dayalı açık ve uzaktan öğrenme uygulamalarında öğrenen-öğrenen ve öğrenen-öğreten etkileşiminin çok sınırlı düzeyde olması veya hiç olmaması nedeniyle öğrenen-içerik etkileşiminin arttırılması öğrenme açısından kilit bir role sahiptir.

Alanyazında etkileşim unsurları içeren videolarla ilgili yapılan araştırmaların daha çok deneysel olarak yapılan ve eklenen etkileşim unsurlarının etkisini ortaya koyan çalışmalar olduğu gözlenmekte; öğrenenlerin etkileşimli videoları kullanma deneyimlerine odaklanan çalışmaların sınırlı düzeyde kaldığı görülmektedir (Delen vd., 2014; Merkt, Weigand, Heier ve Schwan, 2011; Schwan ve Riempp, 2004; Vural 2013; Wachtler vd., 2016; Wilson, 2016; Zhang vd., 2006). Bu çalışma ile alanyazındaki bu boşluğun kapatılması hedeflenmektedir.

\subsection{Etkileşimli Videolar}

Öğrenme deneyimi etkileşimli videolarla daha iyi hale getirilebilmektedir (Cherrett, Wills, Price, Maynard ve Dror, 2009; Schwan ve Riempp, 2004). Bu etkileşimlerin amacı öğrenenlerin dikkatlerini çalışılan konu üzerinde yoğunlaştırmaktır (Wachtler, Khalil, Taraghi ve Ebner, 2016). Videolara eklenen etkileşimler öğrenen-içerik etkileşimini artırmakta böylece öğrenenleri motive etmekte ve öğrenme etkililiğini arttırmaktadır (Zhang vd., 2006). Videolar içerisinde yer verilen etkileşimler ilk başta oynatma, durdurma, ileriye ve geriye sarma biçimindeyken (Delen vd., 2014), çeşitli yazııım ve araçların geliştirilmesi sayesinde bu etkileşim türleri artmıştır. Örneğin, öğrenenler videoları izlerken işaretleme yapma, not ekleme, arama yapma, ek kaynaklar arama, geribildirim alma, sununun hızını ve yönünü değiştirme gibi olanaklara sahip olabilmektedirler (Delen vd., 2014; Dong ve Goh, 2015; Schwan ve Riempp, 2004). Bunların yanı sıra, videolara sorular ve kısa sınavlar eklenebilmektedir (Dong ve Goh, 2015). 
Videolara eklenebilen sorular çeşitli formatlarda sunulabilmekte; bu sorular açık uçlu, eşleştirmeli, doğru-yanlış soruları veya çoktan seçmeli sorular olabilmektedir (Dong ve Goh, 2015; Wachtler vd., 2016). Bu sorular için doğru cevabı gösterme veya cevabın yer aldığı ilgili saniyeye geri dönme gibi geribildirimler etkileşim olarak eklenebilmektedir. Videolar içerisinde yer verilen sorular, öğrenenlerin üst düzey bilişsel düşünme becerilerini geliştirmek, konuyu anlama düzeylerini ve nerede zorlandıklarını ortaya çıkarmak için önemli araçlardır (Wilson, 2016). Lawson, Bodle, Houlette ve Haubner (2006) video izlerken sorulan sorulara yazılı olarak yanıt vermenin öğrenmeyi arttırdığını belirtmektedir. Videoya gömülü sorular, kısa sınavlar ve geribildirimler özellikle kendi kendine çalışma esasına dayalı uzaktan öğrenme ortamlarında öğrenenlerin ders çalışma süreçlerine aktif bir biçimde katılım sağlamasına ve dikkatlerini çalıştıkları konu üzerinde yoğunlaştırmasına yardımcı olur (Dong ve Goh, 2015). Bunlara ek olarak, öğreticilerin biçimlendirici değerlendirme yaparak öğrenenlere anında geribildirim vermelerini sağlar (Bakla, 2017).

Etkileşimli videoların sunduğu analiz araçları sayesinde öğrenenlerin videoları izleyip izlemedikleri ve videodaki sorulara verdikleri yanıtlar takip edilebilmektedir (Bakla, 2017). Not alma, ek kaynaklar arama, sorularla kendini değerlendirme gibi seçenekler öğrenenlere kendi öğrenmelerini yönetme şansı vermektedir (Delen vd., 2014; Wilson, 2016). Bunun yanı sıra, bu etkileşimler öğrenenlerin meta bilişsel ve öz yönetim stratejilerini oluşturmalarına yardımcı olur (Delen vd., 2014).

\section{2. İlgili Araştırmalar}

Etkileşimli videolarla ilgili alanyazındaki araştırmaların genellikle videolara eklenen etkileşim unsurlarının öğrenmeyi, öğrenme süresini, konuya verilen dikkati veya performansı arttırıp arttırmadığını belirlemeye yönelik deneysel çalışmalar olduğu söylenebilir. Yapılan çalışmaların çoğunda eklenen etkileşimlerin öğrenmeyi, öğrenme süresini, konuya verilen dikkati ve performansı arttırdığı ortaya koyulmuştur. Örneğin, Vural (2013) tarafından yapılan deneysel çalışmada soruların gömülü olduğu videoların öğrenmeyi, etkileşim miktarını ve öğrenme malzemelerinin kullanımında harcanan zamanı arttırdığı bulunmuştur. Benzer şekilde, Delen vd. (2014) tarafından yapılan deneysel çalışmada da etkileşimli videoların öğrenme açısından etkileşim unsuru içermeyen videolara göre daha üstün bir eğitsel araç olduğu belirtilmektedir. Zhang vd. (2006) yaptıkları çalışmada etkileşimli video, etkileşimsiz video ve video olmayan üç e-öğrenme ortamı ile geleneksel sınıf ortamını kullanmışlardır. E-öğrenme ortamında etkileşimli videoyla çalışan öğrenenler daha iyi performans göstermişlerdir. Buna bağlı olarak öğrenenlerin memnuniyet düzeyleri daha yüksek çıkmıştır. Bu açıdan, araştırmacılar etkileşimli videoların e-öğrenme sistemlerine entegre edilmesinin önemli olduğunu belirtmektedirler. Merkt vd. (2011), etkileşimli videoların ve resimli kitapların kullanım modellerini ve etkililiğini araştırmıştır. Araştırmada farklı düzeyde etkileşim içeren iki video ve içeriği benzer olan bir kitap kullanılmıştır. Araştırma sonuçlarına göre etkileşimli videoların basılı malzemeler kadar etkili olduğu ortaya çıkmıştır. Öte yandan, durdurma veya arama gibi mikro düzeydeki etkileşimlerin içindekiler listesi veya bir dizin içeren makro düzey etkileşimlere göre öğrenme açısından daha yararlı olduğu sonucu ortaya çıkmıştır. Araştırmacılar bu durumun öğrenenlerin makro düzey etkinliklerin kullanımı konusundaki yanlış yorumlarından kaynaklanabileceğini belirtmişlerdir. 
Schwan ve Riempp (2004) denizci düğümünün öğretimi ile ilgili yaptıkları bir çalışmada durdurma, tekrar oynatma, geriye sarma veya videonun hızını değiştirme gibi etkileşim öğelerini kullanmışlardır. Etkileşimleri kullanmayan öğrenenler denizci düğümünü atabilmek amacıyla gerekli becerileri edinmek için etkileşim olmayan videoları izleyenlere göre daha fazla süreye gereksinim duymuşlardır. Geri vd. (2017), kitlesel açık çevrimiçi derslerdeki videolar üzerinde yaptıkları araştırmada videolara etkileşim öğelerinin eklenmesinin öğrenenlerin dikkat süresini arttırdığını bulmuşlardır.

Öte yandan, Wilson (2016) tarafından yapılan deneysel çalışmada soruların gömülü olduğu matematik videolarının kullanımı ve öğrenenlerin kendi hızında öğrenmelerine olan etkisi araştırılmış; soruların öğrenenlerin dikkatlerini toplamada yardımcı olabileceği bulunsa da videolara gömülü soruların öğrenmeyi arttırdığı ile ilgili bir bulguya rastlanmamıştır.

Wachtler vd. (2016) videolarda çok erken sorulan soruların diğer sorulara göre doğru yanıtlanma ihtimalinin daha düşük olduğunu belirtmektedir. Bu açıdan, ilk sorunun görünme zamanının, video süresinin \%25'inden sonraki zaman diliminde olmasını önermektedirler. Araştırmada ayrıca soruların kısa aralıklarla görünmesinin doğru yanıtlanma ihtimali üzerinde bir etkisinin olmadığı bulunmuştur.

\subsection{Amaç}

Bu çalışmanın amacı, uzaktan öğrenenlere yönelik geliştirilen sorularla zenginleştirilmiş etkileşimli videoların kullanımına ilişkin öğrenenlerin görüşlerinin alınması ve bu görüşlere bağlı olarak kullanılabilirlik, memnuniyet ve gereklilik düzeylerinin araştırımasıdır. Bu kapsamda, aşağıdaki sorulara yanıt aranacaktır:

- Öğrenenler sorularla zenginleştirilmiş videoları hangi düzeyde izlemektedirler?

- Öğrenenler sorularla zenginleştirilmiş videoların kullanılabilirlik düzeyini nasıl değerlendirmektedirler?

- Öğrenenlerin sorularla zenginleştirilmiş videolarla ilgili memnuniyet düzeyleri nasıldır?

- Öğrenenler sorularla zenginleştirilmiş video kullanımının gerekliliğini nasıl değerlendirmektedirler?

\section{Yöntem}

Bu bölümde, etkileşimli videoların öğrenen görüşlerine göre farklı değişkenler açısından araştırıldığı bu çalışma için öncelikle araştırmanın deseni, örneklem, etkileşimli videoların geliştirilmesi, daha sonra ise veri toplama araçları ve analiz aşamaları yer almaktadır. 


\subsection{Araştırma Deseni}

Bu çalışma bağlamında nicel araştırma yöntemlerinden tarama (survey) çalışması kullanılmış ve araştırmanın amacı doğrultusunda kesitsel desen (cross-sectional design) benimsenmiştir. Kesitsel tarama çalışmaları hedeflenen örneklemin belirli bir zaman dilimi içerisinde tutumlarını, düşüncelerini, inançlarını ve davranışlarını belirlemek için kullanılır (Creswell, 2004).

\section{2. Örneklem}

Araştırmanın örneklemi Anadolu Üniversitesi Açıköğretim Fakültesi öğrenme yönetim sistemini kullanan 2393 öğrenendir. Açıöğretim sisteminde 2016-2017 eğitim öğretim yılı itibariyle yaklaşık olarak 1.107.776 aktif öğrenen vardır (Anadolu Üniversitesi, 2017). Bu kapsamda çalışma örneklemi \%99 güven aralığında \%2,5 hata payına sahiptir. Dolayısıyla örneklemin büyüklüğünün evreni temsil etme gücünün yüksek olduğu ifade edilebilir.

\subsection{Etkileşimli Videoların Geliştirilmesi}

Geliştirme aşamasında öncelikle etkileşim (geribildirim) türleri ve soru sayıları belirlenmiştir. Daha sonra soruların ve etkileşimlerin videolara eklenmesini sağlayacak yazııım geliştirilmiş; son olarak sorular ve etkileşimler videolara eklenmiştir.

Etkileşim türlerinin ve soru sayılarının belirlenmesi: Videolar içerisinde yer verilecek sorulardan sonra ekranda öğrenenlere sunulabilecek üç tür etkileşim belirlenmiştir. Bunlar; videoda konunun anlatılığı saniyeye geri dönme, doğru cevabı gösterme ve konunun anlatılığı saniyeye geri dönme veya doğru cevabı gösterme geribildirimlerinden birini seçme (seçenek sunma) biçimindedir (Şekil 1).

Şekil 1. Hata Bildirim Türü

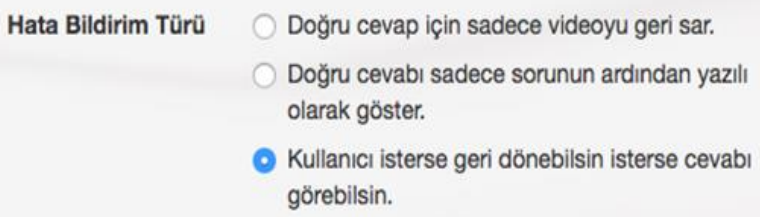

Kaydet

Öncelikle söz konusu etkileşimlerden hangisinin/hangilerinin öğrenenler tarafından daha çok tercih edildiğini ve videolarda kaç adet sorunun kullanılacağını belirlemek için örnek bir video geliştirilmiş ve yarı-yapılandırılmış görüşmelerle beş öğrenenin görüşü alınmıştır. Öğrenenlerin görüşleri doğrultusunda etkileşim türlerine ve soru sayılarına karar verilmiştir. Buna göre, videolara konunun anlatıldığı saniyeye geri dönme veya doğru cevabı gösterme geribildirimlerinden birini seçmeyi 
içeren seçenek sunma etkileşiminin eklenmesi; ayrıca, ortalama 10 dakikalık bir videoda en az üç soru ve etkileşime yer verilmesi kararlaştırılmıştır (Şekil 2).

Şekil 2. Etkileşimli Video Soru Ekleme
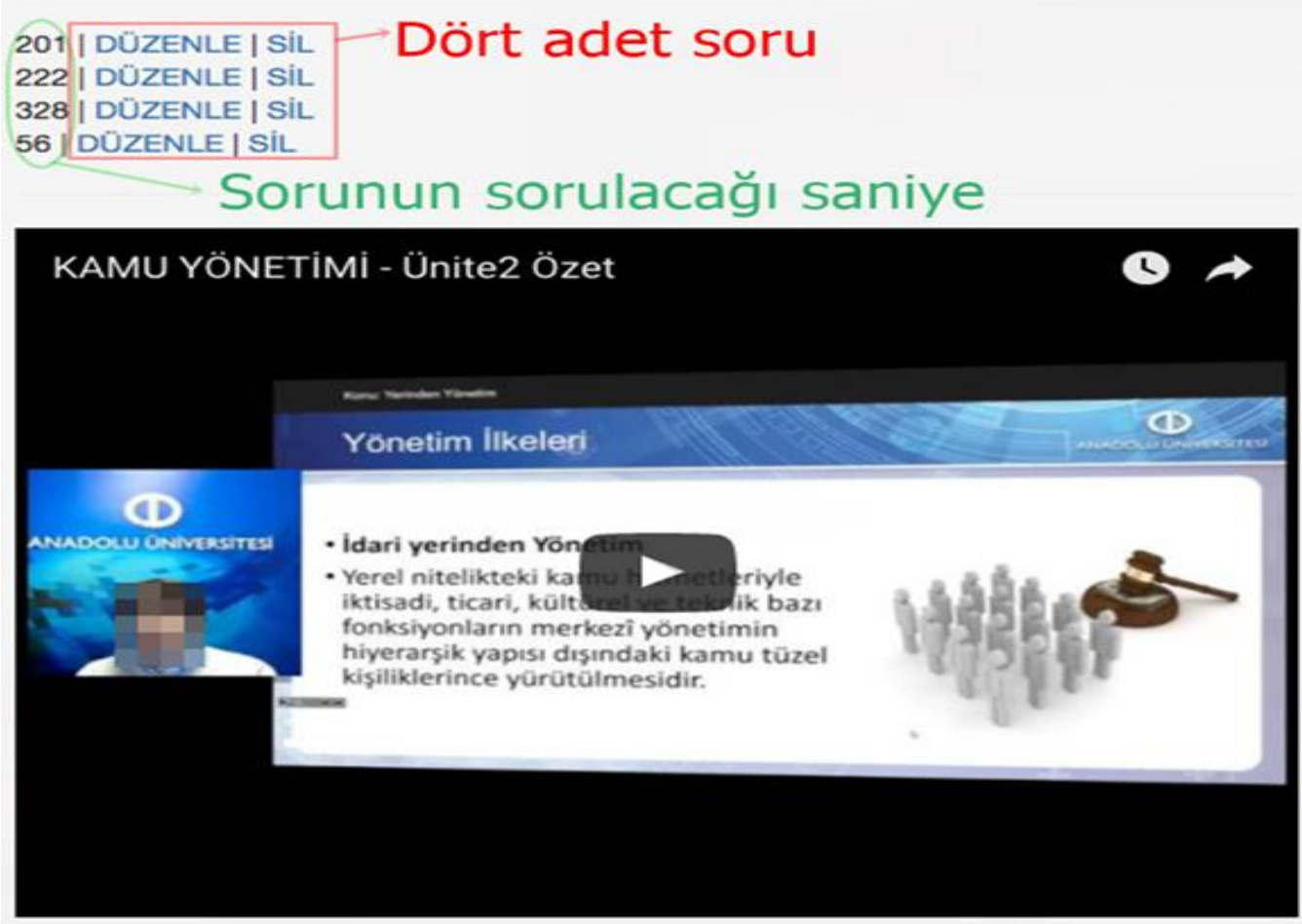

Yazılımın geliştirilmesi: Soruların görüntülenmesinin yanı sıra soruların ve etkileşim türlerinin videolara eklenmesi için iki ayrı yazılım geliştirilmiştir. Bütünleşik olarak çalışan bu sistem, soru havuzundan ilgili videoyla alakalı soruları çekerek video yazılımına aktarma ve etkileşimleri ekleme fonksiyonlarına sahiptir.

Soruların ve etkileşimlerin videolara eklenmesi: Sorular ve etkileşimler geliştirilen yazılım aracılığıyla 15 kişilik bir ekip tarafından videolara eklenmiştir. Videoların üretimi için çalışan ekibe sistemin kullanımı konusunda eğitim verilmiştir. Yaklaşık 150 derste yer alan 1165 adet videoya sorular ve etkileşimler eklenmiştir. Üretimi biten videolar kontrol edilerek gerekli düzeltmeler yapılmış ve hatalı olanlar ayıklanmıştır. Şekil 3'te etkileşimli video üzerinde soruların görünmesi (1), yanıtlanması (2), geribildirim verilmesi (3) ve video sonunda cevap geçmişinin özetlenmesi (4) yer almaktadir. 
Şekil 3. Etkileşimli Video Kullanımı

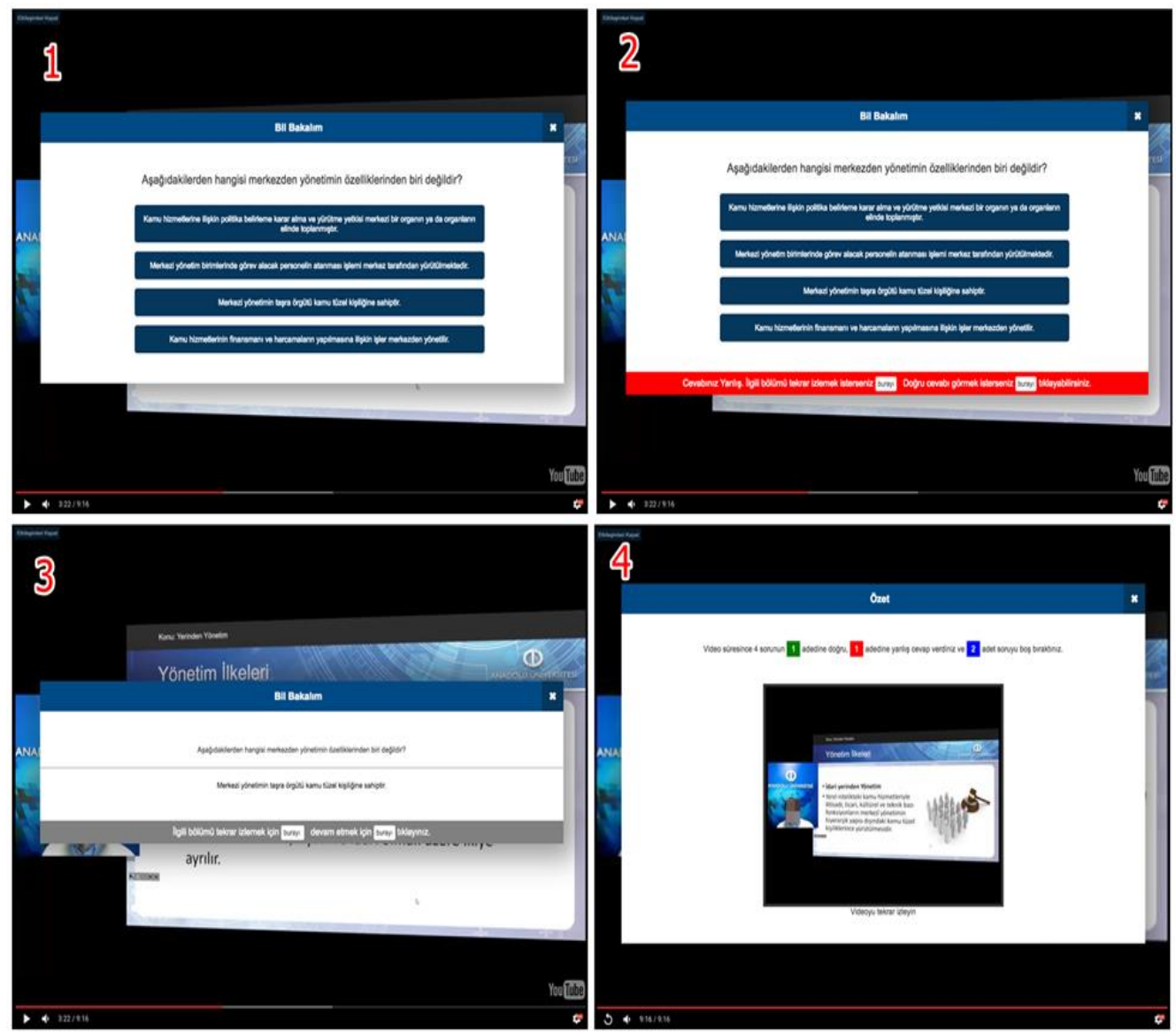

\subsection{Etkileşimli Videoların Uygulanması}

Videolar ünite bazlı olarak konu anlatımı niteliğinde hazırlanmış; yaklaşık 150 derste yer alan 1165 video ilgili ünitenin altına konu anlatımı videosu olarak eklenmiştir. Dönem boyunca öğrenenlerin videolara istedikleri zaman Anadolum e-Kampüs Sistemi üzerinden ulaşmaları sağlanmıştır. Videolar, platform bağımsız olarak PC ortamından kullanılabileceği gibi, diğer mobil araçlardan da sorunsuz erişilebilir olarak tasarımlanmıştır. Öğrenenlere etkileşimli videolara 2016-2017 Bahar dönemi boyunca erişim ve istedikleri zaman izleme imkânı sağlanmıştır. Her videonun altında öğrenenlerin videoları değerlendirmeleri için bir puanlama sistemi ve veri toplama araçları hakkında bilgiler paylaşılmıştır. 


\subsection{Veri Toplama Aracı ve Analizi}

Çalışma kapsamında araştırmacılar 12 maddeden oluşan bir anket geliştirmişlerdir. Anketin iki maddesi çalışmaya katılan öğrenenlerin demografik bilgilerini toplamak için tasarımlanmış, beşli Likert tipi ölçeğin yer aldığı (Hiç katılmıyorum, katılmıyorum, kararsızım, katılıyorum, tamamen katılıyorum) dokuz madde ise öğrenenlerin etkileşimli videolara yönelik görüşlerini belirlemek için kullanılmıştır. Geliştirilen anketin son maddesi açık uçlu soru şeklinde tasarımlanmış ve öğrenenlerden sorularla zenginleştirilmiş videoların öğrenme süreçlerinde kullanımına yönelik düşüncelerini belirtmeleri istenmiştir. Bu veri toplama araçlarına ek olarak öğrenme yönetim sisteminde yer alan analitiklerden ve video altlarına eklenen puanlama ve hata bildirim sisteminden faydalanılmıştır. Elde edilen nicel veriler betimsel istatistikler kullanılarak hesaplanmış ve tablo olarak sunulmuştur. Açık uçlu sorularla toplanan nitel veriler ise kelime bulutu olarak görselleştirilmiş, ayrıca araştırma bulgularını desteklemek için doğrudan alıntılara yer verilmiştir.

\section{Bulgular}

Çalışmaya katılan toplam 2393 öğrenenin \%46,89'u erkek, \%53,11'i ise kadındır. Katılımcıların yaş aralığı incelendiğinde yaklaşık olarak tüm yaş gruplarından öğrenci olduğu görülmektedir. Bununla beraber 22-26, 27-31 ve 37-41 yaş aralığında bir yığılma olduğu gözlenmektedir.

Tablo 1. Öğrenen Demografik Bilgileri

\begin{tabular}{cccccccccccc}
\hline \hline & \multicolumn{1}{c}{ Yaş Kategorisi (f) } & \multicolumn{1}{c}{ Koplam } & \multirow{2}{*}{$\%$} \\
\hline & $17-21$ & $22-26$ & $27-31$ & $32-36$ & $37-41$ & $42-46$ & $47-51$ & $52-56$ & $57-61$ & & \\
\hline Cinsi- Erkek & 53 & 280 & 194 & 149 & 135 & 137 & 105 & 48 & 21 & 1122 & 46,89 \\
yet Kadın & 146 & 281 & 182 & 168 & 210 & 149 & 82 & 36 & 17 & 1271 & 53,11 \\
Toplam & 199 & 561 & 376 & 317 & 345 & 286 & 187 & 84 & 38 & 2393 & 100,00 \\
\hline
\end{tabular}




\section{1. Öğrenenlerin Sorularla Zenginleştirilmiş Videoları İzleme Düzeyleri}

Şekil 4. Etkileşimli Video Puanlama

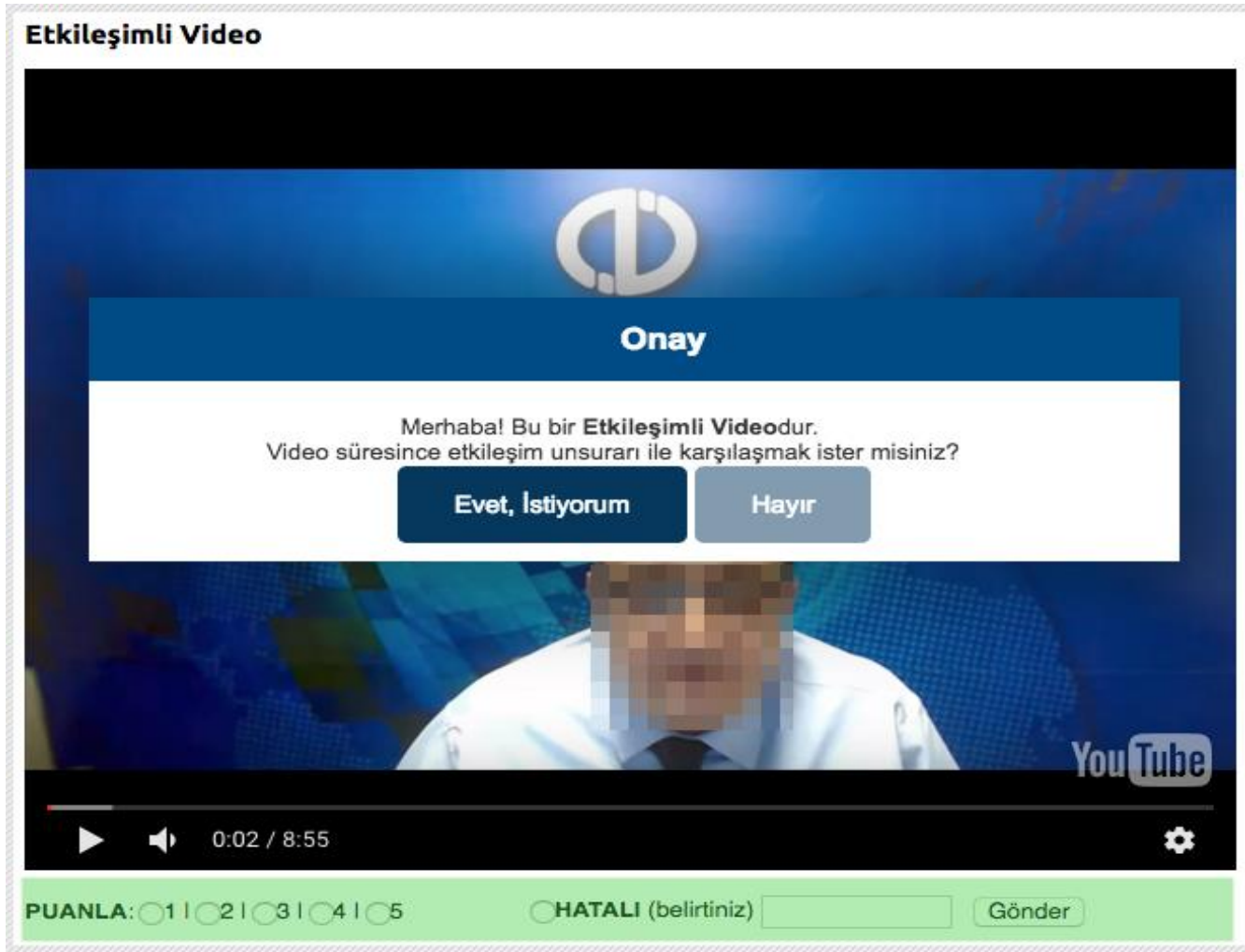

Etkileşimli videolar sanal öğrenme ortamı olarak kullanılan Anadolum e-Kampüs Sisteminde yer alan yaklaşı 500 ders içerisinden yaklaşık 150'sinde yer almıştır ve her bir derste ünite sayısına göre değişkenlik göstermiş olup ortama 7 video yer almaktadır. Bu bağlamda malzeme bazlı öğrenme analitikleri incelendiğinde toplamda 207252 eşsiz kullanıc etkileşimli videoyu kullanmış, her öğrenen ortalama 5.4 farklı videoya erişmiştir. Ortalama etkileşim sayısı olarak ise 8.5 bulunmuştur. Bu da erişim sağlayan kullanıcıların daha sonra tekrar aynı videoya yüksek oranda geri döndüklerinin göstergesidir. Analitiklerden elde edilen bu rakamlara göre öğrenenlerin etkileşimli videoları yüksek oranda izledikleri söylenebilir.

Etkileşimli video malzemelerinin altında kullanıcıların puanlama yapabileceği ve hata bildirebileceği tek satırlık bir eklenti yapılmıştır (Şekil 4). Bu eklentiyle öğrenenler malzeme kalitesini ve özelliklerini puanlayabilmekte ve hatayı belirtebilmektedir. Bu kapsamda 10714 eşsiz puanlayıcı etkileşimli videoyu puanlamıştır (1: 1883, 2: 541, 3: 810, 4:1571, 5: 5748). Öğrenenlerin yaklaşık 
\%70'i 4 ve 5 puanlarını vermişlerdir. Öte yandan, videolara 1 puan veren öğrenenlerin sayısının da yüksek olduğu görülmektedir. Bu bağlamda veriler tekrar gözden geçirilmiş ve 1 puan verip hata bildirimi yapan öğrenenlerin 1400'ünün bu puanı etkileşim unsurlarıyla ilgili olarak değil, internet bağlantı problemi, video içeriği, soru ya da cevap hatası gibi videoyla ilişkili olarak verdiği tespit edilmiştir. Bu bağlamda puanlama sonuçlarına göre öğrenenlerin etkileşimli videoyu yüksek oranda beğendikleri söylenebilir.

\subsection{Sorularla Zenginleştirilmiş Videoların Kullanılabilirlik Düzeyi}

Ankette ilk üç madde kullanılabilirlik ve öğrenenler tarafından algılanan faydayı belirlemek için kullanılmıştır (Tablo 2). Buna göre "iç̧erisinde soruların yer aldığı videoları kullanmak kolaydır" maddesine katılıyorum ve tamamen katılıyorum yanıtını veren kullanıcıların oranı \%91,73'tür. Bu yanıt bağlamında öğrencilerin etkileşimli videoları kullanılabilirliği yüksek bir öğrenme malzemesi olarak değerlendirdiklerini söylemek mümkündür. Katılımcılar "Videolarda sorulara yer verilmesi öğrenmemi kolaylaştııı" maddesine \%94,41, "Videolarda sorulara yer verilmesi derinlemesine düşünmemi sağlar" maddesine \%89,43 oranında olumlu yanıt vermişleridir.

Tablo 2. Öğrenenlerin Etkileşimli Videoların Kullanım Kolaylığı ve Faydaya yönelik Yanıtları

\begin{tabular}{cccccc}
\hline \hline & Cevap Kategorisi & $f$ & $\%$ & Kümülatiff & $\begin{array}{c}\text { Kümülatif } \\
\%\end{array}$ \\
\hline \multirow{2}{*}{ İçerisinde soruların yer } & 5 & 1473 & 61,55 & 1473 & 61,55 \\
aldığı videoları kullanmak & 4 & 722 & 30,17 & 2195 & 91,73 \\
kolaydır. & 3 & 60 & 2,51 & 2255 & 94,23 \\
& 2 & 52 & 2,17 & 2307 & 96,41 \\
& 1 & 86 & 3,59 & 2393 & 100,00 \\
\cline { 2 - 4 } & & 2393 & 100,00 & & \\
\hline & 5 & 1807 & 75,51 & 1807 & 75,51 \\
Videolarda sorulara yer & 4 & 447 & 18,68 & 2254 & 94,19 \\
verilmesi öğrenmemi kolay- & 3 & 44 & 1,84 & 2298 & 96,03 \\
laştırır. & 2 & 27 & 1,13 & 2325 & 97,16 \\
& 1 & 68 & 2,84 & 2393 & 100,00 \\
\cline { 2 - 3 } & & 2393 & 100,00 & & \\
\hline Videolarda sorulara yer & 5 & 1540 & 64,35 & 1540 & 64,35 \\
verilmesi derinlemesine & 4 & 600 & 25,07 & 2140 & 89,43 \\
düşünmemi sağlar. & 3 & 125 & 5,22 & 2265 & 94,65 \\
& 2 & 51 & 2,13 & 2316 & 96,78 \\
& 1 & 77 & 3,22 & 2393 & 100,00 \\
\hline
\end{tabular}

Açık uçlu soruya toplam 898 öğrenen yanıt vermiştir. Öğrenenlerin yanıtlarına göre etkileşimli videoların öğrenenlere sağladığı faydalar öğrenme ve motivasyon olmak üzere 2 tema altında 
toplanabilir. Etkileşimli videoların öğrenmeye yönelik faydaları açısından öğrenenler sorularla zenginleştirilmiş videoların konuyu anlamalarını kolaylaştırdığını, soruların konuyu daha akılda kalıcı hale getirdiğini, sorular sayesinde videoda anlatılanları pekiştirdiklerini, verilen geribildirimlerin çalışma süresi açısından kendilerine zaman tasarrufu sağladığını, konuyla ilgili derinlemesine düşünmelerini sağladığını ve soruların konuyu anlayıp anlamadıklarını ölçmelerine yardımcı olduğunu belirtmişlerdir. Öğrenenlerin yanıtlarından örnekler aşağıdaki gibidir:

- "Anlatılanları o anda pekiştirmiş gibi oluyor. Sorularla zenginleştirilmiş videolar öğrenme açısından güzel bir uygulama."

- "Öğrenmeyi daha etkin hale getirdiğine ve daha verimli bir çalışma ortamı oluşturduğuna inanıyorum."

- "Sorular anlaşılmayan konuların tekrar edilmesini sağlayarak çalışmayı kolaylaştırıyor."

- "Aralarda soruların sorulması daha dikkatli dinlememizi ve konuyu anlamamızı kolaylaştırlyor."

- "Derste nelerin önemli olduğunun altının çizilmesi yönünden çok faydalı buluyorum. Yanlış cevap verdiğimizde o bölümü tekrar izleyebilmek zaman tasarrufu sağlıyor ve konunun pekişmesi için etkili bir yöntem. Öğrenme kalıcı oluyor."

- "Soruların yönlendirici ve konular üzerinde daha çok düşünmeye sevk ettiği bir gerçek."

- "Vidyoyu izlerken daha aktif olmamızı, pekiştirerek öğrenmemize katkı sağlayacağını düşünüyorum."

- Anlatılan konuyu anlayıp anlayamadığımızı ölçmüş oluruz. Yeterli değilsek konuyu tekrar etmemizi sağlar. Böylece konuyla ilgili yanlış ve eksiklerimizi gidermiş oluruz."

- "Sorulan sorular nerede eksiğim olduğunu daha net gösteriyor bana öğrenme sürecime katkısının iyi olacağını düşünüyorum."

- "Sorular sorulması o konuyu ne kadar anlayıp anlamadığımı ortaya çıkarıyor o yüzden soruların olmasından memnunum."

Etkileşimli videoların motivasyona yönelik faydaları açısından öğrenenler videoları daha dikkatli dinlediklerini; başka bir ifadeyle konuya daha iyi odaklandıklarını, öğreticiyle bire bir iletişim halindeymiş gibi kendilerini gerçek bir sınıf ortamında hissettiklerini ve soruların ders videolarını daha eğlenceli ve heyecanlı hale getirdiğini belirtmişlerdir. Buna ek olarak, öğrenenlerden biri videolardaki soruları doğru yanıtlamanın çalışma isteğini arttırdığını vurgulamıştır. Öğrenenlerin yanıtlarından örnekler aşağıdaki gibidir:

- "Aralarda soruların sorulması daha dikkatli dinlememizi ve konuyu anlamamızı kolaylaştırıyor. Harika olmuş emeğinize sağlık." 
Serpil KOÇDAR | Abdulkadir KARADENIZ |Aras BOZKURT | Köksal BÜYÜK

- Beklemediğim bir anda videoyla ilgili sorunun gelmesi dağılan dikkatimi tekrardan kazanmamı sağlayıp odaklanmamı arttırıyor ve bu sayede daha dikkatli ve daha anlayarak dinlemiş oluyorum bu da öğrenmemi kolaylaştırıyor."

- "Bir kere baştan daha dikkatli dinlememizi sağlıyor. Ayrıca monoton gibi gözüken ders videoları daha eğlenceli ve heyecanlı hale geliyor."

- "Kesinlikle verimli olacağını düşünüyorum, videoyu izlerken anlatımdan sonra bir anda sorunun karşıma gelmesi dikkat etmem gerektiğini hatırlatıyor ve soruya yanlıs cevap verip geri döndüğümde konunun artık aklıma yerleşmesini sağlıyor."

- "Sorulara yanıt veremediğinde dikkatini toplaman gerektiğini haber veriyor."

- Videolar içinde soruların olması benim konuya odaklanmamı ve sorulara doğru cevaplar verebilme isteğimi dürtüyor bu açıdan çok güzel bir uygulama olmuş bence daha sık soru sorulmalı."

- "Videoları izlerken genellikle dikkat dağınıklığı yaşadığım ve takip etmekte güçlük çektiğim için sorular dikkatimi toplamamı daha sıkı takip etmemi sağladı. Hani bazı hocalar derste aniden soru sordukları için dersi dinlemek zorunda kalırsın ya onun gibi bir şey:)"

- "Motivasyon olarak mükemmel bir fikir olmuş. Ders çalışma isteğimi ve az önce öğrenmiş olduğum konuyu kapsayan soruya doğru cevap vermek çalışma isteğimi arttırıyor."

- "Dikkatimi toparlamama yardımcı oldu. Videoların sıkıcılığını bir nebze olsun azaltmış."

- "Bu yöntem çok isabetli olmuş daha önce dikkatli dinlemiyordum ama şimdi soru sorulacak diye daha dikkatli dinliyorum."

- "Öğretmen sanki benden yanıt bekliyor takip etme zorunluluğu doğuyor."

- "Anlık soru ve cevaplama olduğu için canlı ders anlatımı hissi veriyor."

- "Sınıf ortamı gibi bize katkıda bulunuyor."

- "Çok fazla ders çalışma yöntemi denedim en yararlısı etkileşimli video oldu."

Dolayısıyla, öğrenenlerin sorularla zenginleştirilmiş etkileşimli videoları öğrenme süreçlerini destekleme bağlamında kullanılabilir ve faydalı bulduklarını söylemek mümkündür.

\section{3. Öğrenenlerin Sorularla Zenginleştirilmiş Videolarla ilgili Memnuniyet Düzeyleri}

Öğrenenlerin memnuniyet düzeylerini belirlemek için anketteki 4., 5., 6. ve 7. maddeler kullanılmıştır (Tablo 3). Öğrenenlerin katılıyorum ve tamamen katılıyorum seçeneklerine verdikleri yanıtlar incelendiğinde "Soruların kullanıldığı videoların her derste olmasını isterim" maddesine \%94,36; "Soruların kullanıldığı videoları izlemekten memnun kaldım” maddesine \%91,85; "içerisinde soruların kullanıldığı videoları arkadaşlarıma tavsiye ederim" maddesine \%91,27; "Videolarda 
yer alan sorular için verilen geribildirimler yeterlidir" maddesine $\% 75,68$ oranında olumlu yanıt verdikleri görülmektedir. Bu veriler ışı̆̆ında öğrenenlerin etkileşimli videoların öğrenme süreçlerinde kullanılmasından memnun olduklarını söylemek mümkündür.

Tablo 3. Öğrencilerin Etkileşimli Videoların Kullanımına Yönelik Memnuniyet Düzeylerine Yönelik Yanıtları

\begin{tabular}{|c|c|c|c|c|c|}
\hline & Cevap Kategorisi & $f$ & $\%$ & Kümülatif $f$ & Kümülatif \% \\
\hline \multirow{6}{*}{$\begin{array}{l}\text { Soruların kullanıldığı } \\
\text { videoların her derste } \\
\text { olmasını isterim. }\end{array}$} & 5 & 1843 & 77,02 & 1843 & 77,02 \\
\hline & 4 & 415 & 17,34 & 2258 & 94,36 \\
\hline & 3 & 39 & 1,63 & 2297 & 95,99 \\
\hline & 2 & 31 & 1,30 & 2328 & 97,28 \\
\hline & 1 & 65 & 2,72 & 2393 & 100,00 \\
\hline & & 2393 & 100,00 & & \\
\hline \multirow{6}{*}{$\begin{array}{l}\text { Soruların kullanıldığı } \\
\text { videoları izlemekten } \\
\text { memnun kaldım. }\end{array}$} & 5 & 1653 & 69,08 & 1653 & 69,08 \\
\hline & 4 & 545 & 22,77 & 2198 & 91,85 \\
\hline & 3 & 48 & 2,01 & 2246 & 93,86 \\
\hline & 2 & 51 & 2,13 & 2297 & 95,99 \\
\hline & 1 & 96 & 4,01 & 2393 & 100,00 \\
\hline & & 2393 & 100,00 & & \\
\hline \multirow{6}{*}{$\begin{array}{c}\text { İçerisinde soruların kul- } \\
\text { lanılı̆ı̆ı videoları arka- } \\
\text { daşlarıma tavsiye ede- } \\
\text { rim. }\end{array}$} & 5 & 1620 & 67,70 & 1620 & 67,70 \\
\hline & 4 & 564 & 23,57 & 2184 & 91,27 \\
\hline & 3 & 82 & 3,43 & 2266 & 94,69 \\
\hline & 2 & 45 & 1,88 & 2311 & 96,57 \\
\hline & 1 & 82 & 3,43 & 2393 & 100,00 \\
\hline & & 2393 & 100,00 & & \\
\hline \multirow{6}{*}{$\begin{array}{l}\text { Videolarda yer alan soru- } \\
\text { lar için verilen geribildi- } \\
\text { rimler yeterlidir. }\end{array}$} & 5 & 1095 & 45,76 & 1095 & 45,76 \\
\hline & 4 & 716 & 29,92 & 1811 & 75,68 \\
\hline & 3 & 308 & 12,87 & 2119 & 88,55 \\
\hline & 2 & 155 & 6,48 & 2274 & 95,03 \\
\hline & 1 & 119 & 4,97 & 2393 & 100,00 \\
\hline & & 2393 & 100,00 & & \\
\hline
\end{tabular}

Öğrenenlerin açık uçlu soruya verdikleri yanıtlar sorularla zenginleştirilmiş etkileşimli videoların öğrenme sürecinde kullanılmasından duydukları memnuniyeti göstermektedir. Öğrenenler etkileşimli videoları nitelerken "başarılı, güzel, harika, mükemmel, yararlı, faydalı" gibi sıfatlar kullanarak memnuniyetlerini ifade etmişlerdir. Öğrenenlerin açık uçlu soruya verdikleri yanıtlardan örnekler aşă̆ıdaki gibidir:

- "Gayet başarılı bir uygulama, konuyu anlama açısından pekiştirici."

- "Güzel bir uygulama olmuş. Ders tekrarını ve öğrenmeyi kolaylaştırıyor. Ayrıca konu anlatım videoları da bir yıl çok profesyonelce hazırlanmış. Memnun kaldım." 
- "Harika bir fikir. Öğrenmeyi basitleştiriyor ve kolay anlaşılmasını sağlıyor. Ayrıca anında bilgimizi test etmemizi sağlıyor."

- "Mükemmel bir çalışma, okuduğumuzu anlamamıza büyük destek olmuş."

- "Faydalı olduğunu düşünüyorum, yararlı olacaktır."

Açık uçlu soruya yanıt veren 898 katılımcının yanıtları kelime bulutu haline getirilmiş, en az 15 frekansa sahip 100 kelime görselleştirilmiştir. Şekil 5'te görüleceği üzere en çok kullanılan ilk beş kelime daha $(n=401)$, çok $(n=263)$, soru, $(n=142)$, iyi $(n=131)$ ve güzel $(n=96)$ şeklindedir. Ortaya çıkan bu durum çalışmaya katılan öğrencilerin genel görüşünü ve memnuniyetini betimlemek açısından ayrıca ilgi çekicidir.

Şekil 5. Katılımcı Yanıtlarından Oluşturulan Kelime Bulutu

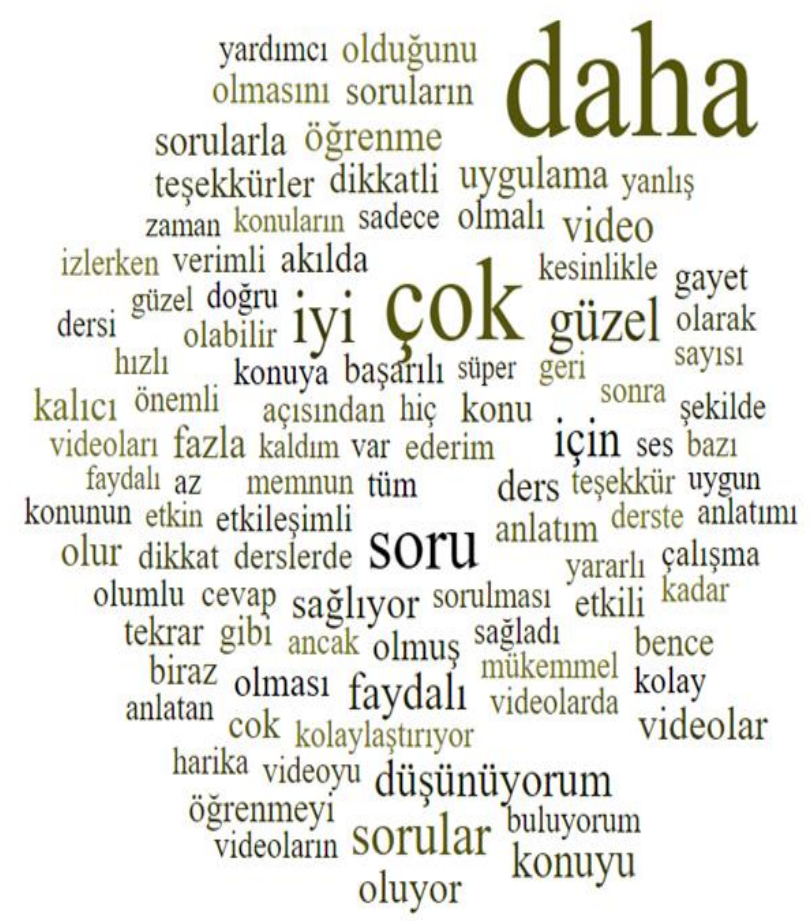


Öte yandan, açık uçlu sorulara yanıt veren 898 kişiden 64'ü olumsuz yorumlarda bulunmuşlardır. Olumsuz yorumların 60'ı bazı videoların süresinin kısa olması, ses kalitesi, dersi anlatan kişi ve bazı soruların niteliği ile ilgili olup, 4'ü etkileşimli videolardan memnun olmadığını ve bu videoları yararı bulmadığını söyleyen öğrenenlere aittir. Etkileşimli videolardan memnun kalmadıklarını belirten öğrenenlerin yanıtları aşağıdaki gibidir:

- Konu anlatımı hemen sırasında sorulması doğru değil bence bu pekiştirmeye faydalı mıdır tartışılır ama bence hiç etik değil."

- "Pat diye soru çıkıyor ne diyordu ne oluyor kalıyorsun bir anda, teşekkürler ben beğenmedim."

- “Çok yüzeysel buldum. Önce kitaptan bilgilendirseniz çok yetersiz gelecektir."

- "Videolar içerisinde soru sorulmasını uygun bulmuyorum karşılıklı canlı bir iletişim yok, gerek de yok."

\subsection{Sorularla Zenginleştirilmiş Video Kullanım Gerekliliği}

Anketin 8. ve 9. maddeleri öğrenenlerin etkileşimli videoları gelecekte kullanma olasılıklarını ve bu öğrenme malzemelerinin öğrenme süreçlerinde gerekliliğine yönelik düşüncelerini belirlemeyi amaçlamaktadır. Öğrenen cevapları katııyorum ve tamamen katılıyorum seçeneklerine verdikleri yanıtlara göre incelendiğinde "Soruların yer verildiği videoların kullanımı yaygınlaştırılmalıdır" maddesine \%94,27; "Videolarda sorulara yer verilmesi gerekir" maddesine ise \%93,23 oranında olumlu yanıt verdikleri görülmüştür. Dolayısıyla etkileşimli videoların öğrenenler tarafından öğrenme süreçlerinde gerekli bir malzeme olduğunu ve farklı öğrenme süreçlerinde de benzer etkileşimli malzemelerin olması gerektiğini düşündüklerini söylemek mümkündür.

Tablo 4. Öğrenenlerin Etkileşimli Videoların Gerekliliği ve Gelecekte Kullanma Olasılıklarına yönelik Yanıtları

\begin{tabular}{cccccc}
\hline \hline & Cevap Kategorisi & $\mathrm{f}$ & $\%$ & Kümülatif $\mathrm{f}$ & Kümülatif \% \\
\hline & 5 & 1680 & 70,20 & 1680 & 70,20 \\
Videolarda sorulara & 4 & 551 & 23,03 & 2231 & 93,23 \\
yer verilmesi gerekir. & 3 & 64 & 2,67 & 2295 & 95,90 \\
& 2 & 32 & 1,34 & 2327 & 97,24 \\
& 1 & 66 & 2,76 & 2393 & 100,00 \\
\cline { 2 - 4 } & & 2393 & 100,00 & & \\
\cline { 1 - 4 } Soruların yer verildiği & 5 & 1869 & 78,10 & 1869 & 78,10 \\
videoların kullanımı & 3 & 387 & 16,17 & 2256 & 94,27 \\
yaygınlaştırılmalıdır. & 2 & 41 & 1,71 & 2297 & 95,99 \\
& 1 & 27 & 1,13 & 2324 & 97,12 \\
\cline { 1 - 3 } & & 69 & 2,88 & 2393 & 100,00 \\
\hline
\end{tabular}


Öğrenenlerin açık uçlu sorularla verdikleri cevaplar da etkileşimli videoların kullanımının yaygınlaştırılması yönündedir. Öğrenen yanıtlarında sadece etkileşimli video sayısının değil, aynı zamanda etkileşimli videolarda sorulan soru sayısının da artıııması gerektiği bulgularına ulaşıımıştır. Öğrenenlerin açık uçlu soruya verdikleri yanıtlarından örnekler aşağıdaki gibidir:

- "Çok yararlı olduğunu düşünüyorum ve her derse uygulanmasını rica ediyorum."

- "Daha çok videoda kullanılması etkin ve devamlı tekrarı ve sürekli öğrenmeyle birlikte konuların akılda daha iyi bir şekilde kalmasını sağlayacaktır."

- "Yerinde ve olumlu bir çalışma olduğunu düşünüyorum. Bu uygulamanın tüm derslere uygulanması taraftarıyım."

- "Kesinlikle çok faydalı öğrenme açısından da daha akılda kalıı soru-cevap video şeklinde olması, her dersten olmasını ve soru sayılarının arttırılmasını isterim."

- "Konuyu daha iyi anlamamı sağlıyor, anlatılan dersleri daha dikkatli dinliyorum, bu soruların bütün derslerde olmasını ve soru adetinin artırılmasını istiyorum."

- "Kullanımı çok basit. Kesinlikle bütün derslerde olmalı daha iyi öğrenmeyi sağlıyor."

- "Faydalı buluyor ve arttırılmasını bekliyorum."

- Bazı öğrenenler, etkileşimli videoların yaygınlaştırılması gerektiğini söylemekle birlikte, bazı önerilerde bulunmuşlardır. Bu öneriler; geribildirimlerde daha fazla açıklamaya yer verilmesi, videolara daha fazla soru eklenmesi ve video süresinin daha uzun olması olarak sayılabilir.

\section{Tartışma, Sonuç ve Öneriler}

Öğrenme süreçlerinde etkileşim birçok önemli görevi yerine getiren bir unsurdur (Anderson, 2003; Uğur ve Okur, 2016). Hatta bazı araştırmacılara göre etkileşim öğrenme süreçlerinde en kritik öğedir (Kearsley, 1995) ve başarıya ulaşabilmek için etkileşimin sağlanması gerekmektedir (Mclsaac \& Gunawardena, 1996). Xiao (2017), uzaktan öğrenme alanyazınında öğrenen-içerik etkileşimine odaklanan çalışmalara olması gerektiğinden daha az yer verildiğini; uzaktan öğrenenlerin içeriği nasıl çalıştıklarını anlamak için daha fazla çaba harcanması gerektiğini ve öğrenen-içerik etkileşimiyle ilgili araştırmalarla desteklenmeyen uzaktan öğrenme ders malzemelerinin öğrenenlerin ihtiyaçlarını karşılamaktan uzak kalabileceğini belirtmektedir. Buna bağı olarak bu çalışma, açık ve uzaktan öğrenmede öğrenen-içerik etkileşimini arttırmaya yönelik olarak kullanılabilecek sorularla zenginleştirilmiş etkileşimli videolarla ilgili öğrenen deneyimlerine odaklanmaktadır. Bu kapsamda, çalışmanın amacı uzaktan öğrenenlere yönelik geliştirilen etkileşimli videolara ilişkin izlenme düzeyi, kullanılabilirlik, öğrenen memnuniyeti ve kullanım gerekliliği açılarından öğrenenlerin görüşlerinin belirlenmesidir. 
Araştırma sonucunda elde edilen bulgulara göre öğrenenlerin \%90'ından fazlası sorularla zenginleştirilmiş etkileşimli videolarla çalışmaktan memnun olduklarını belirtmiş, etkileşimli videoların öğrenme süreçlerinde gerekli bir malzeme olduğunu ve uygulamanın diğer derslere de yaygınlaştırılmasını istemişlerdir. Öğrenenler sorularla zenginleştirilmiş videoları yüksek oranda kullanarak bu videoları kolay kullanılabilir ve oldukça faydalı bulmuşlardır; her bir öğrenen ortalama 5.4 farklı videoya erişerek farklı veya aynı videoları ortalama 8.5 kez izlemiştir. Alanyazında yer alan çalışmalar etkileşimli videoların öğrenme, dikkati yoğunlaştırma ve aktif öğrenme deneyimi sağlama açısından olumlu faydaları olduğunu göstermektedir (Bakla, 2017; Delen vd., 2014; Dong ve Goh, 2015; Vural, 2013; Wachtler vd., 2016; Zhang vd., 2006). Bu çalışmada elde edilen öğrenen görüşleri de alanyazındaki bulguları desteklemektedir. Buna göre, öğrenenler kendilerine sunulan sorularla zenginleştirilmiş etkileşimli videoların konuyu daha iyi anlamaya, kalıcı öğrenmeye, öğrenme süresinin kısalarak zaman tasarrufu sağlanmasına, derinlemesine düşünmeye, konuyu pekiştirmeye, öz-değerlendirme yapmaya, dikkati yoğunlaştırarak daha iyi odaklanmaya ve eğlenceli bir öğrenme deneyimi yaşamaya katkıda bulunduğunu belirtmişlerdir.

Çalışma bulguları aynı zamanda ortam zenginliği kuramında yer alan açıklamaları desteklemektedir (Daft ve Lengel, 1984). Buna göre ortam zenginliği kuramı çerçevesinde tasarımlanan öğretim araçları öğrenme kaynağı ile iletişimin artması; öğrenenin içeriğe zengin ve çoklu iletişim kanallarından ulaşabilmesi; iletişim sürecinde çabuk geribildirim alabilmesi; içeriğin ve iletişim kanallarının zenginliğinden dolayı öğrenenin kendine uygun iletişim şeklini seçerek bireysel öğrenmesine ve zengin öğrenme deneyimleri elde edebilmesine olanak sağlamaktadır.

Buna karşılık, alanyazından farklı olarak bu çalışmada bazı öğrenenler sorularla zenginleştirilmiş etkileşimli videoların kendilerini gerçek bir sınıf ortamında gibi öğreticiyle karşı karşıya hissetmelerini sağladıklarını belirtmişlerdir. Bu açıdan, sorularla zenginleştirilmiş etkileşimli videoların öğrenenlerin alanyazında önemi sıkça vurgulanan; çevrimiçi öğrenme ortamlarında etkileşim kavramını açıklamaya yarayan Sorgulama Toplulukları (Communities of Inquiry-COI) (Garrison, Anderson ve Archer, 1999) modelinin bir öğesi olan öğretim bulunuşluğunu (teaching presence) arttırmaya katkıda bulunabileceği söylenebilir. Öğretim bulunuşluğu, bireysel olarak anlamlı ve eğitsel açıdan yararlı öğrenme çıktılarını sağlayabilmek için bilişsel ve sosyal süreçlerin tasarımı, kolaylaştırılması ve yönetilmesi olarak tanımlanmaktadır (Garrison vd., 1999). Öğretim bulunuşluğu çevrimiçi bir öğrenme topluluğunu birbirine bağlayan ve etkili çevrimiçi öğrenme için gereken bilişsel ve sosyal aktivitelerin gerçekleşmesini sağlayan bir öğedir (Garrison vd., 1999). Bu kapsamda, videolara sorular ve geribildirimler içeren aktiviteler eklenmesinin öğretim bulunuşluğuna olumlu etkisi olduğu söylenebilir. Sorgulama Toplulukları modelinin diğer bir öğesi ise bilişsel bulunuşluktur. Bilişsel bulunuşluk, anlamı yapılandırma, anlama ve anlayış geliştirme olarak ifade edilebilir (Garrison vd., 1999). Bu çalışmada sorularla zenginleştirilmiş videoların öğrenen-içerik etkileşimini arttırarak öğrenme süreçlerinde kolaylık sağlaması açısından öğrenenlerin bilişsel bulunuşluğuna da olumlu katkıda bulunduğu ileri sürülebilir.

Bu çalışmada elde edilen bir diğer bulgu, öğrenenlerin sorulara verilen geribildirimlerde daha fazla açımlamaya gereksinim duymaları olmuştur. Bu sonuç, alanyazında Gibbs ve Simpson (2004); 
Gibbs, Simpson ve Macdonald (2003); Pridemore ve Klein (1991) tarafından yapılan araştırmaları desteklemektedir. Bu çalışmalara göre öğrenenler daha fazla detay içeren geribildirimleri tercih etmişlerdir. Araştırmalar, en iyi geribildirim türünün hangisi olduğu konusunu aydınlatamasa da daha fazla açımlama içeren türlerin daha fazla öğrenme sağladığı görüşü ağırlık kazanmaktadır (Koçdar, 2006). Açık ve uzaktan öğrenmede çeşitli düzeylerde açımlama içeren geribildirim türleri öğrenmeyi etkilemese de bağımsız öğrenme için önemli bir bileşendir (Mandernach, 2005). Bunun yanı sıra, geribildirim, uzaktan öğrenenlerin başarıya ulaşmak için sahip olmaları gereken özyönetimli öğrenme becerilerini geliştirme açısından da önemli bir unsurdur (Butler ve Winne, 1995; Van Den Boom, Paas, Van Merrienboer ve Van Gog (2004). Öte yandan, geribildirim türü; öğrenenlerin başarma düzeyleri, öğrenme materyalinin niteliği, öğrenenlerin anlama yeteneğinin boyutu gibi değişkenler tarafından etkilenmektedir. Mason ve Bruning (2001), öğrenenlerin bilgi düzeyleri arttıkça ve öğrenilen konu zorlaştıkça daha az açımlamalı geribildirimin daha yararlı olabileceğini belirtmektedir. Bu araştırmada sorulara verilen geribildirim miktarı bir değişken olarak ele alınmamıştır; ancak etkileşimli videolarda sorulara verilecek ideal geribildirim miktarının belirlenmesi için öğrenenlerin sınıf ve bilgi düzeylerinin dikkate alınacağı farklı araştırmalara gereksinim duyulduğu söylenebilir.

Bu çalışmada videolar içerisinde yer verilen sorulara ilişkin geribildirimler, metin formatında verilmiştir. Ice, Curtis, Phillips ve Wells (2007) sesli geribildirim vermenin metin formatındaki geribildirimlerle karşılaştırıldığında öğrenen memnuniyetini arttırdığını; hatta sesli geribildirimlerin öğrenenlerin topluluk olma hissini (sense of community) arttırabileceğini belirtmektedir. İleride yapılacak çalışmalarda etkileşimli videolar içerisinde sesli geribildirimler verilerek bu geribildirimlerin öğrenme, motivasyon, öğretim bulunuşluğu veya bilişsel bulunuşluk açılarından etkisi araştırılabilir. Fakat bu tür çalışmalarda içeriğin sunumunda ikili kodlama (dual coding) kuramında da açıklandığı üzere aynı kanalların kullanılmasıyla bilişsel yük (cognitive load) getirmemesine (Mayer ve Moreno, 2003) öğrenme içeriklerinin tasarımında dikkat edilmelidir.

Bu araştırmanın sonuçlarına göre öğrenenler videolarda yer verilen soru sayısının arttırılmasını istemişlerdir. Öte yandan, soru sayısının fazla olmasının öğrenenlerin dikkatini dağıtabileceği göz ardı edilmemelidir. Geri vd. (2017), etkileşimin dikkati toplama ve öğrenme kalitesini arttırma açısından olumlu etkilere sahip olduğunu vurgulasalar da etkileşimin öğrenenleri rahatsı edici ve dikkat dağıtıcı bir unsur olarak da görülebileceğini belirtmektedirler. Bu durumda, videolara eklenecek soru sayılarının daha kapsamlı araştırmalara dayalı olarak belirlenmesi gerektiği söylenebilir; soru eklenmesiyle amaç, öğrenenlere bir soru havuzu sunulması değil, etkileşimi arttırarak onların dikkatini çekmek ve daha etkili ve verimli öğrenmelerini sağlamaktır. Bu araştırmada soru sayıları 5 öğrenenin görüşlerine göre belirlenmiştir; ideal soru sayılarının belirlenmesine ilişkin daha geniş çaplı araştırmalar yapılabilir.

Bu araştırmada öğrenenlerin sorulara verdikleri yanıtlar dikkate alınmamıştır. Gelecekte yapılacak diğer araştırmalarda öğrenenlerin etkileşimli videolarda sorulara doğru yanıt verme oranlarının da dikkate alındığı araştırmalar yapılabilir. Böylece, öğrenenlerin hangi sorularda yanlış yaptıkla- 
rı tespit edilerek öğrenme malzemelerinde gerekli iyileştirmeler yapılabilir. Buna ek olarak, sorularla zenginleştirilmiş etkileşimli videoları daha çekici ve eğlenceli kılmak için videolara oyunlaştırma öğeleri dahil edilerek öğrenenlere doğru yanıtladıkları sorular için puan verilebilir. Bunların yanı sıra, videolara sorular dışında farklı etkileşim öğeleri eklenebilir.

\section{Kaynaklar}

Anadolu Üniversitesi. (2017). Öğrenci sayıları. https://www.anadolu.edu.tr/ universitemiz/say ilarla-universitemiz/ogrenci-sayilari/2016-2017-ogrenci-sayilari/eylul-2016

Anderson, T. (2003). Modes of interaction in distance education: Recent developments and research questions. İçinde M. G. Moore (ed.), Handbook of distance education (pp. 129-144). Mahwah, NJ.: Erlbaum.

Aydın, C. H. (2011). Açık ve uzaktan öğrenme: Öğrenci adaylarının bakış açısı. Ankara: Pegem Akademi.

Bakla, A. (2017). Interactive videos in foreign language instruction: A new gadget in your toolbox. Mersin Üniversitesi Eğitim Fakültesi Dergisi, 13(1), 124-137.

Butler, D. L., ve P.H. Winne. (1995). Feedback and self-regulated learning: A theoretical synthesis. Review of Educational Research, 65 (3), 245-281.

Cherrett, T., Wills, G., Price, J., Maynard, S., \& Dror, I. E. (2009). Making training more cognitively effective: Making videos interactive. British Journal of Educational Technology, 40(6), 11241134.

Daft, R. \& Lengel, R. (1984). Information richness: A new approach to managerial behavior and organization design. İçinde B. M. Staw \& L. L. Cummings (Eds.), Research in organizational behavior (pp.191- 233). Greenwich, CT: JAI Press.

Delen, E., Liew, J., \& Willson, W. (2014). Effects of interactivity and instructional scaffolding on learning: Self-regulation in online video-based environments. Computers \& Education, 78, 312-320.

Dong, C., \& Goh, P. S. (2015). Twelve tips for the effective use of videos in medical education. Medical Teacher, 37(2), 140-145.

Garrison, D.R., Anderson, T., \& Archer, W. (1999). Critical inquiry in a text-based environment: Computer conferencing in higher education. The Internet and Higher Education, 2 (2-3), 87105.

Geri, N., Winer, A., \& Zaks, B. (2017). Probing the effect of interactivity in online video lectures on the attention span of students: A learning analytics approach. Chais Konferansi'nda sunulan bildiri. İsrail. 
Gibbs, G., \& Simpson, C. (2004). Conditions under which assessment supports students' learning. Learning and Teaching in Higher Education, 1, 3-31.

Gibbs G., Simpson, C., \& Macdonald, R. (2003). Improving student learning through changing assessment - A conceptual and practical framework. EARLI Konferansi'nda sunulan bildiri, Padova.

Ice, P., Curtis, R., Phillips, P., \& Wells, J. (2007). Using asynchronous audio feedback to enhance teaching presence and students' sense of community. Journal of Asynchronous Learning Networks, 11(2), 3-25.

Kearsley, G. (1995). The nature and value of interaction in distance learning. Distance Education Symposium 3: Interaction'da sunulan bildiri, University Park, Pennsylvania State University.

Koçdar, S. (2006). Uzaktan eğitim ders kitaplarının geribildirim açısından değerlendirilmesi: Anadolu Üniversitesi'nin uzaktan eğitim veren Işsletme ve iktisat Fakülteleri örneği (Yüksek lisans tezi). http://libra.anadolu.edu.tr/libra.aspx?IS=DETAY\&SP=5240973534497324\&N1 $=\& N 2=\& \mathrm{KN}=354053$ adresinden alınmıştır.

Lawson, T. J., Bodle, J.H., Houlette, M. A., \& Haubner, R.R. (2006). Guiding questions enhance student learning from educational videos. Teaching of Psychology, 33(1). 31-33.

Mandernach, B. J. (2005). Relative effectiveness of computer-based and human feedback for enhancing student learning. The Journal of Educators Online, 2(1), 1-17.

Mason, B. J., \& Bruning, R.H. (2001). Providing feedback in computer-based instruction: What the research tells us. CLASS Research Report No. 9. Center for Instructional Innovation, University of Nebraska-Lincoln.

Mayer, R. E., \& Moreno, R. (2003). Nine ways to reduce cognitive load in multimedia learning. Educational Psychologist, 38(1), 43-52.

Mclsaac, M. S., \& Gunawardena, C. N. (1996). Distance education. İçinde D. H. Jonassen (Ed.), Handbook of research for educational communications and technology: A project of the Association for Educational Communications and Technology (pp. 403-437). New York: Simon \& Schuster Macmillan.

Merkt, M., Weigand, S., Heier, A., \& Schwan, S. (2011). Learning with videos vs. learning with print: The role of interactive features. Learning and Instruction, 21, 687-704.

Moore, M. G., \& Kearsley, G. (2012). Distance education: A systems view of online learning. Belmont, CA: Wadsworth-Cengage Learning.

Pridemore, D. R., \& Klein, J. D. (1991). Control of feedback in computer-assisted instruction. Educational Technology Research and Development, 39(4), 27-32. 
Schwan, S., \& Riempp, R. (2004). The cognitive benefits of interactive videos: Learning to tie nautical knots. Learning and Instruction, 14, 293-305.

Uğur, S., \& Okur, M. R. (2016). Açık ve uzaktan öğrenmede etkileşimli video kullanımı. AUAd, 2(4), 104-126.

Xiao, J. (2017). Learner-content interaction in distance education: The weakest link in interaction research. Distance Education, 38(1), 123-135.

Van Den Boom, G., Paas, F., Van Merrienboer, J.J.G., Van Gog, T. (2004). Reflection prompts and tutor feedback in a web-based learning environment: Effects on students' self-regulated learning competence. Computers in Human Behavior, 20(4), 551-567.

Vural, O. F. (2013). The impact of a question-embedded video-based learning tool on e-learning. Educational Sciences: Theory and Practice, 13(2), 1315-1323.

Wachtler, J., Hubmann, M., Zöhrer, H., \& Ebner, M. (2016). An analysis of the use and effect of questions in interactive learning-videos. Smart Learning Environments, 3(13), 1-16.

Wachtler, J., Khalil, M., Taraghi, B., \& Ebner, M. (2016). On using learning analytics to track the activity of interactive MOOC videos. LAK'16 Konferansı'nda SE@VBL 2016 Çalıştayı, Edinburgh, Scotland.

Wilson, A.D. (2016). The flipped approach: The use of embedded questions in math videos (Yüksek lisans tezi). https://search.proquest.com/docview/1803639473?pq-origsite=gscholar adresinden ulaşılabilir.

Zhang, D., Zhou, L., Briggs, R.O., \& Nunamaker, J.F. (2006). Instructional video in e-learning: Assessing the impact of interactive video on learning effectiveness. Information \& Managemt, 43(1),15-27 